\title{
On the Necessity of Sinicizing Marxism from the Perspective of Actual Needs
}

\author{
Yunjian Gao, Yuting Xiao, Hanzhou Gao \\ Guangdong University of Foreign Studies, Guangzhou, China \\ Email: 13724947924@163.com
}

How to cite this paper: Gao, Y. J., Xiao, Y. T., \& Gao, H. Z. (2020). On the Necessity of Sinicizing Marxism from the Perspective of Actual Needs. Open Journal of Social Sciences, 8, 566-573.

https://doi.org/10.4236/jss.2020.84041

Received: February 12, 2020

Accepted: April 27, 2020

Published: April 30, 2020

Copyright $\odot 2020$ by author(s) and Scientific Research Publishing Inc. This work is licensed under the Creative Commons Attribution International License (CC BY 4.0).

http://creativecommons.org/licenses/by/4.0/

\begin{abstract}
Though it originated in the west, Marxism succeeded in adapting itself to the actual conditions in China and had become the guiding ideology for China's revolution, development and reform. This is all because of actual needs: the urgent need for social reforms and development in China since modern times have provided rich soil for the sinicization of Marxism; the urgent need of the Chinese people towards freedom has been the direct driving force; and the need for Chinese traditions to keep up with the times has offered an opportunity.
\end{abstract}

\section{Keywords}

Need, Marxism, Sinicization

If there are no actual needs, even the best theory won't make sense or work. As Carl Marx said, "the extent to which theory is realized in a country is always determined by the degree to which the theory meets the needs of the country" (Marx \& Engels, 1995). Marxism can be accepted by the Chinese people and develop into Chinese Marxism in practice, thus settling the Chinese problem that the practice proves that no other theory can be resolved because it meets the need of progress of Chinese society, people being the masters of the country and the interflow of cultures. Mao Zedong once highly valued it: "the reason why Marxism-Leninism came to China has played such a big role is because China's social conditions have such a need, because it was associated with the practice of the Chinese people's revolution, because it was controlled by the Chinese people" (Mao, 1991).

\section{The Urgent Need for the Survival of China's Nature and Transformation in Modern Times Has Made Marxism a Profound Soil in China}

1) Changing the nature of China's semi-colonial and semi-feudal society, 
and saving the destiny of the Chinese nation require a scientific and advanced theory to guide, and the scientific and advanced nature of Marxism itself makes it stand out among many theories, it was favored and chosen by the Chinese people

As is known to all, since the Opium War of 1848, China has been reduced from a feudal society to a semi-colonial and semi-feudal society. At that time, China was attacked and plundered by colonial countries, and the land of the motherland has been destroyed, and the people's life is very painful. The survival of the nation became an imminent historical mission of the Chinese nation. In the form of salvation, countless benevolent people have carried out arduous exploration and struggle. Among them, including the Taiping Heavenly Kingdom Movement led by Hong Xiuquan, the Reform Movement of 1898 initiated by Kang Youwei, the Yihetuan Movement (Known in the West as the Boxer Uprising) led by Yan Shuqin and Zhao Sanduo, etc., although they fought again and again, they failed again and again, and they paid a very big price; the Revolution of 1911 led by Dr. Sun Yat-sen. Although overthrowing the monarchy system that lasted for thousands years is of great significance to promoting China's social progress, it still fails to change the nature of China's semi-colonial and semi-feudal society. In the ideological world, there are also many bloody Chinese people that have been heated debates about "problems and doctrines", for example, the dispute between Hu Shi and Li Dazhao; and there have been attempts to use the Western doctrines of Dewey's pragmatism, Darwin's theory of evolution, and Rousseau's theory of the inalienable rights of man to solve the historical problem of where China is going. For example, Yan Fu systematically introduced Darwin's evolution theory and opposed the monarchy with Rousseau's innate theory of human rights. But practice has proved that these claims cannot fundamentally resolve the historical problems of China. Finally, the victory of the October Revolution in Russia brought the Chinese intellectuals who had grown up in the "May 4th" New Culture Movement, the dawn of the salvation. They believed the science and truth of Marxist theory, resolutely decided to use Marxism. Guided by it, the Chinese Communist Party was established. "Our party is based on the Marxist-Leninist theory since its establishment. Because this is the most correct and revolutionary science theory among proletariat in the world. Once the universal truth of Marxism-Leninism is combined with the concrete practice of the Chinese revolution, it will make the Chinese revolution powerful." (Mao, 1991a)-Mao Zedong once commented that this is indeed an indisputable historical fact. Under the leadership of the Communist Party of China, the Chinese Communists combined the universal principles of Marxism with the concrete practice of the Chinese revolution (For example, according to Marx's thoughts on class struggle and the elimination of private ownership, the Chinese communists put forward the theory that the red power in China could come into being, exist and develop, and blaze a revolutionary path of relying on the countryside, establishing the armed forces of workers and peasants, surrounding the cities with the countryside and finally winning the national victo- 
ry), and create the Chinese Marxism-Maoism, brought brilliant victory of the Northern Expedition, the Agrarian Revolutionary War, the War of Resistance Against Japan, and the War of Liberation, the establishment of the People's Republic of China. Completed the history of the semi-feudal and semi-feudal society of the old China, completely abolished all unequal treaties imposed by the powers on China, and completely changed the state of being scattered in the old China and opened a new era of Chinese social form.

To sum up, in terms of China's social environment at that time, actually provides a deep soil of marxism into China: on the one hand, the May 4th New Cultural Movement, broke the feudal thought and brings the thought liberation, ideological circle appeared the situation of "a hundred flowers blossom, a hundred schools of thought contend", it provided a free ideological environment for marxism to enter China; On the other hand, the European continent was a scene of desolation after the world war 1914-1918, which made China lose confidence in the western capitalist civilization, but Russia's October revolution, which broke out in the latter part of the war, offered China an alternative. Moreover, the theories of Marx, Lenin and others advocating national equality and opposing aggression are like the light of hope, warming the Chinese people who have been bullied by imperialism.

\section{2) Developing socialism still needs Marxism as a guide}

Some people think that Marxism is a philosophy of criticism and philosophy of struggle. Therefore, after the victory of the revolution, it has completed its historical mission, meaning that the stage of socialist development does not necessarily require Marxism as a guide. Can this really be true? Sure, Marxism is about the philosophy of criticism and the philosophy of struggle, but this is not the whole of Marxism. Marxism is fundamentally a scientific system composed of basic principles and basic concepts. We must understand it completely and accurately. Deng Xiaoping has warned future generations: "For Marxism-Leninism, we should understand this system accurately and completely ... or we must make mistakes" (Deng, 1994).

Practice has proved that the development of socialism, especially the building of socialism with Chinese characteristics, must also be guided by Marxism. Although Marxism originated in Europe during the development of capitalism, it absorbed all the achievements of civilization in the history of human thought beyond the stage of capitalism, as Lenin said: "The revolutionary proletarian ideology of Marxism has won the historical significance of the world because it did not abandon the most precious achievements of the bourgeois era, but instead absorbed and transformed all the valuable things in the development of human thought and culture for more than two thousand years (Lenin, 1995). Therefore, it has the scientific nature of theory and the universality of truth. The qualification of Marxism to become the guiding ideology of the cause of socialism with Chinese characteristics lies in its "scientific" and "universality", but the Chinese communists are well aware of Marxism-the essence of Marxism-seeking truth from facts. Therefore, whether in the revolution or in the construction pe- 
riod or in the reform period, they openly opposed to dogmatism, highly emphasize the enrichment and development of Marxism in practice. Xi Jinping pointed out at the annual general meeting celebrated the establishment of the Communist Party of China: "Not forgetting the initial heart and moving on, we must adhere to the guiding position of Marxism, adhere to the close combination of the basic principles of Marxism with the reality and the characteristics of the times in contemporary China, promote theoretical innovation, practical innovation, and constantly push the Sinicization of Marxism forward" (Xi, 2018a). In the great practice of socialism with Chinese characteristics, our party has produced the latest achievements of Marxism in China, which is in line with Marxism, Deng Xiaoping Theory, Jiang Zeming's “three represents” thought, $\mathrm{Hu}$ Jintao's outlook on scientific development, and Xi Jinping's socialism with Chinese characteristics in the new era. These achievements are the most concrete manifestation of the Chinese Communists using Marxism to transform China, and are the guiding ideology for advancing the great cause of socialism with Chinese characteristics. Adhering to these guiding ideologies is to truly uphold Marxism. Under the depressed circumstance of global international communist movement, the cause of socialism with Chinese characteristics has achieved brilliant achievements in the world, and the socialist road has gradually demonstrated its glorious prospects. Especially in the current international financial crisis, the drawbacks of capitalist society have become more exposed, the superiority of socialism is becoming more and more prominent.

Marxism depicts the laws and blueprints for the evolution of human society from low to high. Socialism and communism are the advanced stage and beautiful form of human society. We should have enough confidence in this. Although the road is long, the there may be repetitions, but the future must be bright. Deng Xiaoping has had a profound exposition: "I firmly believe that there will be more people in the world who agree with Marxism, because Marxism is science" (Xu et al., 1999). Xi Jinping also said: "Not forgetting the initial heart and moving on, is to say that we must remember that our party has determined its struggle for communism and socialism as its own program since its establishment, and has strengthened the great ideal of communism and the common ideal of socialism with Chinese characteristics, constantly pushing forward the great practice of striving for lofty ideals" (Xi, 2018b).

\section{The Urgent Need of the Chinese People to Turn Themselves into Liberation and Be the Masters of the Country Has Directly Promoted the Marxism in China}

The modern history of China is a history of people being oppressed by imperialism, feudalism and bureaucratic capitalism. The people lack basic human dignity. The warning sign "Chinese and dogs are not allowed to enter" in Shanghai Concession Park is the most powerful portrayal of the Chinese people in that era.

In a sense, Marxism is about the theory of the proletariat. It calls for "the pro- 
letarians of the world unite!" It blew the horn to the world: "Get up, the slaves who are hungry and cold! Get up, the people who suffer in the world!" The blood of the fullness has already boiled, and we must fight for the truth! ... Don't say that we have nothing, we must be the masters of the world!" (quoted from the "Internationale" lyrics). Such a theory makes the Chinese people who are suffering from disasters such as spring breeze, such as bright light of liberation. The Chinese Communists, represented by Mao Zedong, combined the basic principles of Marxism with the concrete practices of the Chinese revolution, taking the working class as the main body and the workers and peasants alliance on the basis of strength. In pursuit of the goal to seek national independence and people's liberation as the fundamental, the main body strategically opens up the correct path of using rural areas to encircle the city and finally capturing the city, and stipulate the people's democracy led by the working class and based on the alliance of workers and peasants. In the state polity, all the rights of the state belong to the people, and the organs of the people exercising state rights are the whole nation. The people's congresses and local people's congresses at various levels. It can be seen that the Communist Party of China who is armed with Marxism and does everything for the people, is a Marxist party that represents the fundamental interests of the people. Just like Mao Zedong said: "Another notable sign that our Communists are different from any other political party is to get the closest connection with the broadest masses of the people. Serve the people wholeheartedly, and never leave the masses; everything starts from the interests of the people rather than individuals or small groups; being accountable to the people and responsible for the party's leadership; these are our starting points" (Mao, 1991b). It takes the people's need to turn to liberation and be the master of the country as a fundamental need, and relies on the people to realize this need and shake off the centuries of shame. If we say that the need to change the social nature of Chinese semi-colonial and semi-feudal provides a profound soil for Marxism's Chinese, then the need for the people to turn to liberation and be the master of the house provides a direct thrust for Marxism in China. With a deep soil and direct thrust, the seed of Marxism in China has the basic conditions to grow and root.

Someone may ask again, that was the age of war, but now it is a period of peace, then why do you still need Marxism as a guide?

Undoubtedly, Marxism is needed in the war years, and Marxism is also needed in peacetime. Because Marxism is a developed theory, emancipating the mind, seeking truth from facts and advancing with the times is the theoretical quality of Marxism. People's freedom and emancipation requires Marxism, people's all-round development is the same; the pursuit of national independence and liberation of the people calls for marxism, as does the realization of national rejuvenation and common prosperity. Marxism can be the guiding ideology in peacetime because serving the people is its eternal theme, it is an open system, and it can absorb abundant nourishment in the new era and new practice. True marxists must recognize and stick to the quality of keeping pace with 
The Times, keep pace with The Times, make breakthroughs and make achievements.

\section{The Need for Chinese Traditional Culture to Adapt to the Needs of Sinicizing Marxism}

In general, integration or exclusion may occur between different cultures. A culture accepts another culture, unless it has the need to transform itself or has a similar concept to another, or it can be exclusion.

As a foreign cultural form, Marxism can resolve China's contradictions and solve China's problems. There is no doubt that it is compatible with Chinese traditional culture.

First of all, the need for Chinese traditional culture to keep up with times has made it more inclusive. It should be noted that the traditional Chinese culture has a long history and its broad and profound intension. It has played an irreplaceable and important historical role in promoting the development of Chinese society. If we do not admit this, we will make a mistake of cultural nihilism, our nation will become a rootless nation without cultural accumulation and guidance. However, as we all know, the Chinese traditional culture is based on the maintenance of the feudal ruler's imperial power, with a strong feudal society. In modern times, China has been reduced to a semi-colonial and semi-feudal country, not only the invasion of foreign capitalist culture, but also the germination of the national bourgeois culture in our country, the Chinese traditional culture has been strongly impacted. In order to seek the truth to save the country, various domestic cultural trends have stirred up each other. The "May 4th" New Culture Movement has pushed this cultural trend to a climax, and the Chinese traditional culture can no longer adhere to the original model and Content, it needs to be integrated into the elements of the new era, and at this time, the strongest voice of the new era-Marxism from Russia came to China, after the fierce debates on "problems and doctrines" in the Chinese ideological circles, advanced Chinese intellectuals finally chose to use Marxism to solve China's problems among many options. Why not choose "traditional wisdom" but choose Marxism? In this regard, Mao Zedong made an incisive answer when talking about Confucius with Yan Yaming in 1942: Confucius is indeed a very great figure in Chinese history. There are negative things in his thoughts, and positive things that can only be used as history, need to inherit and develop critically. For the current revolutionary movement, he is the second thing. The first to guide the revolutionary movement is Marxism theory (Kuang, 1985). This answer not only clarifies the positioning of Chinese traditional culture in the current situation, but also clarifies the positioning of Marxism in the current situation. Whether it is "first place" or "second place", "for the current revolutionary movement "is all very important, and both are changing to meet the needs of the current revolutionary movement."

Secondly, there are many similarities between Chinese traditional culture and 
Marxism in the concept, so that the two can blend together and avoid the conflict.

With regard to the social blueprint, Chinese traditional culture holds the idea of "the ideal world", while Marxism advocates the establishment of a socialist society in the form of equal and free public ownership in which the people are masters of their own affairs until the communist society. Moreover, at the practical level, the Chinese people have also made positive attempts, such as the Taiping Heavenly Kingdom Movement mentioned above, advocating the establishment of an ideal society of "each having fields to plough, food to eat, clothes to wear, and money to spend. Everyone is well fed and clothed." Marx called the Taiping Heavenly Kingdom the first regime of a communist nature in the world and once called the Taiping Heavenly Kingdom the "Chinese Republic".

In terms of official-people relations, Chinese traditional culture advocates, "Distribute property equitably and treat people in different positions equally, worry before the people worry, and not be happy until the people are happy", while Marxism holds that "the people are the masters of the world" and that "the people, only the people, are the driving force for the creation of world history.", and advocate "serving the people wholeheartedly".

With regard to talents, Chinese traditional culture advocates that "one has his own value" and "everyone can give full play to his abilities", while Marxism advocates the freedom and all-round development of human beings.

With regard to philosophy, Chinese traditional culture advocates "atheism" and "the Doctrine of the mean". Marxism, on the other hand, advocates materialism and dialectics.

All these "similar" provide an opportunity for the combination of the two. With regard to the similarities between the two, a sketch published by Guo Moruo in the 1920s, Marx entering the Confucius Temple, described it vividly: "Marx (to Confucius) said, "I can't think of an old comrade like you in the far east, and your views are completely the same" (Guo, 1985). It is difficult to imagine that without similar views between the two, the psychological defense of Chinese intellectuals would not pass and the spread of Marxism in China would not be so smooth.

\section{Conclusion}

To sum up, it is precisely because Marxism is needed by the Chinese nation, Chinese society and the Chinese people in transforming society, returning to the all-round free development of human beings and cultural fit, that once this theory is mastered in China, China will take on a new look, and the Chinese people will have a great leap from standing up, getting rich to becoming strong.

\section{Study Limitations}

The limitation of this study is that only three perspectives are selected for analysis. In fact, Marxist thought on ethics, also known as Marxist moral theory, is an 
organic part of Marxism. It emphasizes that people's moral values are ultimately constrained by their socio-economic relations, while acknowledging that morality is counterproductive to socio-economic relations and to social life as a whole. And the moral theory of Chinese society also has a long history. Through the comparative analysis of these aspects, I think it will be another good perspective for us to fully and deeply understand why Marxism can be sinicized, which is worth further discussion.

\section{Conflicts of Interest}

The authors declare no conflicts of interest regarding the publication of this paper.

\section{References}

Deng, X. P. (1994). Selected Works of Deng Xiaoping (Vol. 2). Beijing: People's Publishing House.

Guo, M. R. (1985). Complete Works of Guo Moruo (Literature Volume, Volume 10). Beijing: People's Literature Publishing House.

Kuang, Y. M. (1985). Confucius Review (p. 474). Shandong: QiluShushe.

Lenin (1995). Selected Works of Lenin (Vol. 4, p. 299). Beijing: People’s Publishing House.

Mao, Z. D. (1991). Selected Works of Mao Zedong (Vol. 4, p. 1515). Beijing: People's Publishing House.

Mao, Z. D. (1991a) On the Coalition Government, Mao Zedong's Selected Works (2nd Edition, Vol. 3, p. 1094). Beijing: People's Publishing House.

Mao, Z. D. (1991b). On the Coalition Government, Mao Zedong's Selected Works (2nd Edition, Vol. 3, pp. 1094-1095,). Beijing: People’s Publishing House.

Marx \& Engels (1995). Selected Works of Marx and Engels (Vol. 1, p. 11). Beijing: People's Publishing House.

Xi, J. P. (2018a). Speech at the Celebration of the 95th Anniversary of the Founding of the Communist Party of China (July 1, 2016), Selected Works of Important Documents since the 18th National Congress (Part 2) (p. 345). Central Literature Publishing House.

Xi, J. P. (2018b). Speech at the Celebration of the 95th Anniversary of the Founding of the Communist Party of China (July 1, 2016), Selected Works of Important Documents since the 18th National Congress (Part 2) (p. 347). Central Literature Publishing House.

Xu, Q. P., et al. (1999). Selected Readings of Marxism (p. 498). Beijing: Higher Education Press. 